\title{
Research on the Application of Decorative Painting Art in Modern Design*
}

\author{
Yan Zhou \\ Zhuhai College of Jilin University \\ Zhuhai, China 519041
}

\begin{abstract}
Decorative painting is a comprehensive form of expression of fine arts. It takes nature as a medium, breaking through the limitation of natural objects, and deliberately pursuing the artistic quality of its modeling and expression, thus to highlight the decorative language, and then to achieve the purpose of integration of painting and technology. With the improvement of material standard of living, people have higher requirements for modern design. As an important part of modern design, decorative painting has become a key issue for designers to think about how to apply this art form reasonably so as to highlight the artistic nature of design. Through the analysis of the artistic characteristics of decorative painting, this paper briefly analyzes its form of expression and application in modern design.
\end{abstract}

Keywords-decorative painting; modern design; artistic features; application

\section{INTRODUCTION}

Decorative painting is the most basic and important element in the field of decoration with a variety of styles and rich connotation. It takes into account the dual characteristics of painting and decoration, And in the long-term development, it has gradually formed the function of independent artistic appreciation and beautification of the environment. The decoration painting appearing on the wall of the east - west cave in prehistoric times, although the painting content and method were very different from those in the modern design , the same in the function of decoration. After entering the modern society, the means of expression and artistic connotation of decorative painting are gradually enriched. Meanwhile, with the gradual improvement of people's aesthetic pursuit, decorative painting not only has decorative functions, but also embodies certain cultural connotations and aesthetic characteristics. At the same time, it also reflects people's ideal of life and conveys people's aesthetic feelings.

\section{THE ARTISTIC CHARACTERISTICS OF DECORATIVE PAINTING}

\section{A. Various Forms of Composition}

The artistic characters of decorative painting emphasize

*Guangdong social science foundation project: Guangdong province advertising major comprehensive reform pilot project No. 2014009.

Teaching Quality Engineering Project of Guangdong Education Department: Zhuhai Institute of Jilin University-Zhuhai Huaxiang General Aviation Co., Ltd. Practical Teaching Base, Project No. 2015002 stability, concentration and balance in composition, but in modern design, the common composition includes horizontal body composition, stereoscopic composition, combined composition, stacked composition and so on. The horizontal body composition uses the vertical relation between the painting image and the vision to express the balanced visual effect, the stereoscopic composition arranges the position of the drawing object by fixing the drawing orientation, to produce the stereoscopic effect of the visual extension. Combined composition is to use the contrast between different painting images to emphasize the theme of design; and the stacked composition to a certain theme starts painting to highlight the decorative effect of the hierarchy.

\section{B. The Unique Style}

The shape of decorative painting is closely related to a particular theme. Designers in the process of choosing decorative painting, on the one hand, use the change of decorative image unity, symmetrical balance, to highlight the rigor of painting, so as to ensure theme fit of the decorative painting art and the corresponding design; on the other hand, designers usually adopt simplified and abstract ways to integrate all kinds of decorative painting elements in order to ensure the plane feeling of plastic arts, and then deepen the level of decorative painting modeling. It can not only highlight the depth of modeling, but also make it full, enrich the artistic connotation.

\section{Emphasis on Visual Effects}

Decorative painting art is the product of the combination of painting art and decorative design art. In the process of practice, designers generally have no fixed tools and design techniques, and all artistic effects are based on the visual feeling of space. In decorative painting design, designers usually break down the realistic style of painting and choose a more modern artistic way to achieve visual expression. For example, in order to highlight the theme of modern design, designers will use exaggeration and deformation techniques to show the artistic connotation of painting, so that the viewer broadens the space for thinking in the visual impact.

\section{Combination of Art and Technology}

Decorative painting is the product of a certain stage of human spiritual civilization and aesthetic needs, that is, people's demand for space has broken through the simple 
residential value, and began to develop to aesthetic value. Therefore, the use of some simple lines, colors, painting decoration space has become the seed of decorative painting. In modern design, decorative painting from the beautification function, its artistry has been further expanded, but its basic value has not changed. Of course, with the development of modern painting and decorative technology, increasingly exquisite of decorative painting technology, designers can flexibly use modern technology to integrate decorative painting in the design, and then enhance the artistic charm of space.

\section{THE MANIFESTATION OF DECORATIVE PAINTING IN MODERN DESIGN}

First of all, the basis of painting is as a form of expression. Point, line, surface, these basic painting elements, are also the main form of decorative painting art. There is no limitation on length, width and thickness of the points, and different visual effects can be produced through artistic arrangement. In decorative painting, the designer can use the change of lines to reflect the artistic nature of the painting object, thus making the painting effect more changeable and natural. While the expression of surface in painting is more specific and more advantageous, designers can use bulk form to influence the spatial structure. Secondly, take the material texture as the expression form. The texture of the material is manifested in the texture structure of the material, the decorative painting selects the painting material according to the different subject matter, the composition, the modeling, and uses the natural texture to select the painting image, the color, and different textures produce different visual effects. For example, the vague and soft texture will give people a profound feeling, while the crisp and clear texture will give people the previous sense of progress. The combination of different textures can make the designer's expression more smooth and flexible. Thirdly, abstract art is taken as the form of expression. Abstract art is more and more widely used in modern design. The so-called abstraction is the spiritual connotation and implicit beauty summed up from reality. In modern decoration, designers can break the traditional figurative decorative effect, draw lines and generalize the art, and use concise lines and colors to convey the artistic idea and aesthetic value. Such artistic expression can not only enrich the artistic language of decorative painting, but also enrich the artistic imagination of visitors. Finally, color composition is used as a form of expression. Color composition is the basic theory of modern design. The color concept in modern decorative painting art presents the characteristics of purifications and symbolization, and different colors inspire different psychological experiences. Therefore, in modern design, designers usually choose decorative painting colors from the perspective of psychology.

\section{APPliCATION OF DECORATIVE PAINTING ART IN MODERN DESIGN}

\section{A. Ensuring the Mutual Benefit of Decorative Painting and Interior Space Design}

In modern design, in order to ensure the harmonious unity of decorative painting art and space, we must make a choice of decorative painting on the basis of defining the basic functions of space. Under the pressure of modern society, people have higher requirements for space decoration. For example, in interior design, some people want to feel the freshness of nature in the increasingly polluted urban environment, so designers should try their best to focus on fresh, warm and natural colors in the color selection of decorative paintings. Only in this way can we improve the aesthetic value of space by making use of the interaction between space and decorative painting on the basis of meeting the needs of users.

\section{B. Paying More Attention to the Use of Decorative Painting Color in Modern Design}

The color expression of decorative painting art has been briefly described in the preceding part. Therefore, designers should attach importance to color selection in modern design based on the relationship between color and spatial structure of decorative paintings. Color is not only the main means for designers to embody decorative art, but also an important way to express spatial structure. For example, in interior design, designers should try their best to give priority to warm tone in order to highlight the warm feeling of living at home, and at the same time, collocate the corresponding cold tone to balance the spatial structure; In addition, in the process of using color, designers should pay attention to the effect of light to ensure that the light and color can complement each other.

\section{Choosing Modern Decorative Painting According to Different Functions of Space}

With the improvement of material standard of living, people's pursuit of spiritual life becomes more intense. In modern design, designers use different decorative painting art, which can not only stimulate people's thoughts and feelings, but also enable people to obtain richer and more comfortable visual enjoyment through certain sensory stimulation. For example, in the modern interior design, designers often use some of the traditional culture elements, the spatial function division, to highlight the adornment effect, at the same time the use of explicit or contact foil means emphasis on indoor function, so as to create a good artistic atmosphere.

\section{CONCLUSION}

In short, in modern design, decorative painting art plays an important role. When the indoor space plays its basic function value, if the painting works can be correctly selected for decoration, it can not only enrich the content of the space, but also convey the aesthetic feelings of the users. Therefore, in modern design, the designer should choose the decorative painting according to the artistic characteristics of decorative painting and its basic performance in the design, so that the indoor space in color and structure presents a harmonious and natural aesthetic sense.

\section{REFERENCES}

[1] Mou Yanxuan. Thinking About The Application Of Decorative Painting Art In Modern Design [J]. Mass Literature And Art. 2016, 05: 76-77. 牟 彦宣. 思考装饰绘画艺术在现代设计中的应用 $[\mathrm{J}]$. 大众文 艺, 2016,05:76-77. 
[2] Kang Lingling. Application And Practice Of Decorative Painting Art In Modern Design [J]. Art Education Research. 2016, 14: 55. 康玲玲. 装 饰绘画艺术在现代设计中的应用与实践探究 [J]. 美术教育研 究,2016,14:55.

[3] Li Yuhong. Application Of Decorative Painting Art In Modern Design [J]. Grand Stage, 2015 05: 67-68. 李雨虹. 装饰绘画艺术在现代设计 中的应用[J]. 大舞台,2015,05:67-68.

[4] Yu Rong. Study On The Application Of Modern Decorative Painting In Interior Design [J]. Art \& Science \& Technology. 2015,08: 44. 玉荣. 现 代装饰绘画在室内设计中的应用研究[J]. 艺条科技, 2015,08:44. 